\title{
Lack of correlation between in vitro and in vivo effects of low density lipoprotein on the inflammatory activity of monosodium urate crystals
}

\author{
T P GORDON ${ }^{1}$ P CLIFTON, ${ }^{2}$ M J JAMES, ${ }^{3}$ AND P J ROBERTS-THOMSON ${ }^{1}$
}

From the Departments of ${ }^{1}$ Clinical Immunology, ${ }^{2}$ Biochemistry, and ${ }^{3}$ Surgery, Flinders Medical Centre, Bedford Park, South Australia

SUMmARY The effect of coating monosodium urate crystals (MSU) with low density lipoprotein (LDL), postulated previously as a major regulator of gouty inflammation, was studied in a neutrophil chemiluminesce (CL) assay and an air pouch model of inflammation induced by MSU. LDL crystalline coating abrogated the neutrophil CL response but, in contrast, had no inhibitory effect on leucocyte accumulation, levels of the prostaglandin (PG) metabolite 6-keto-PGF $1 \alpha$, and exudation of plasma proteins in the in vivo model. This latter observation raises doubts about the postulated physiological role of LDL in terminating the acute gouty attack.

Key words: gouty inflammation, apoprotein B-containing lipoproteins.

The interaction of monosodium urate crystals (MSU) with neutrophils is a critical feature in the pathogenesis of acute gout, ${ }^{1}$ but the factors modulating this interaction are still uncertain. One modulator likely to be important is crystalline protein coating. ${ }^{2-5}$ Serum and plasma coats markedly inhibit neutrophil oxidative and lytic responses to $\mathrm{MSU}^{2}{ }^{4}$; this effect has been shown to be due to coating of crystals by lipoproteins containing apoprotein B (apo B). ${ }^{6}$ It has been proposed that ingress of lipoproteins into the joint space during urate crystal induced synovitis may be responsible for terminating the acute attack. ${ }^{6}$

To date there have been no reports on the effect of apo B lipoproteins on the biological activity of urate crystals in vivo. We have compared the effect of these lipoproteins in two models: MSU induced neutrophil chemiluminescence (CL), and urate crystal induced inflammation in the rat subcutaneous air pouch. Surprisingly, coating with low density lipoprotein (LDL), the apo B lipoprotein with the largest inhibitory effect, abrogated the oxidative response of human neutrophils to MSU in vitro, yet had no effect on the phlogistic activity of the crystals in vivo.

Accepted for publication 16 January 1986.

Correspondence to Dr P J Roberts-Thomson, Department of Clinical Immunology, Flinders Medical Centre, Bedford Park, South Australia 5042.

\section{Materials and methods}

LIPOPROTEIN DEPLETION AND ISOLATION Normal human serum (NHS) was brought to a density of $1.21 \mathrm{~g} / \mathrm{ml}$ with solid $\mathrm{KBr}$ and spun at $40000 \mathrm{rpm}$ for $40 \mathrm{~h}$ at $4^{\circ} \mathrm{C}$ in a Beckman Ti50 rotor in a Beckman L5-65 ultracentrifuge. Centrifuge tubes were sliced in the middle of the clear section. The top fraction was then applied to the Superose $6 \mathrm{~B}$ column for lipoprotein separation. The bottom fraction was retained as lipoprotein free serum (LPFS) and dialysed against Dulbecco's phosphate buffered saline (PBS) before use. Control NHS was spun as above, but the lipoprotein fraction was remixed with the LPFS after tube slicing and the serum then dialysed against PBS. Lipoproteins in the serum fraction of density $<1.21 \mathrm{~g} / \mathrm{ml}$ were subjected to gel filtration chromatography, which was performed at room temperature with Superose $6 \mathrm{~B}$ and a K 16/70 chromatographic column $(1.6 \times 56$ $\mathrm{cm}$ ) in conjunction with the Pharmacia fast protein liquid chromatography system. The equilibrating and eluting solution contained $0 \cdot 15 \mathrm{M} \mathrm{NaCl}, 0 \cdot 01 \%$ $\mathrm{Na}_{2}$ EDTA (sodium ethylenediaminetetra-acetate), and $0.02 \% \mathrm{NaN}_{3}$. This solution was degassed and filtered through a $0.22 \mu \mathrm{m}$ Millipore filter (Millipore Corp., Bedford, Mass, USA) before use. Fractions were eluted at a rate of $45 \mathrm{ml} / \mathrm{h}$ and the absorbance of eluate monitored continuously at $280 \mathrm{~nm}$. Clear 
separation of very low density lipoprotein (VLDL), low density lipoprotein (LDL), and high density lipoprotein (HDL) was obtained with this system.

\section{CRYSTALS}

MSU crystals $2-20 \mu \mathrm{m}$ in length were prepared by a modification of the method of Denko and Whitehouse. ${ }^{7} 8$ Crystals were coated with $50 \%$ control NHS diluted in Dulbecco's phosphate buffered saline (PBS); $50 \%$ lipoprotein free serum (LPFS) diluted in PBS; $50 \%$ LPFS reconstituted with original serum concentrations of VLDL, LDL, or HDL; and purified LDL $(1 \mathrm{mg} / \mathrm{ml})$, in a ratio of $10 \mathrm{mg}$ crystals per $1 \mathrm{ml}$ of protein solution. Unbound protein was removed as described previously and crystals resuspended in urate saturated PBS. ${ }^{8}$ Control (uncoated) crystals were washed equally and suspended in urate saturated PBS.

CHEMILUMINESCENCE ASSAY

The CL response of human neutrophils to MSU was measured at $37^{\circ} \mathrm{C}$ in an LKB luminometer (model

Table 1 Effect on crystal induced CL of coating MSU with serum in the presence and absence of lipoprotein fractions

\begin{tabular}{lcl}
\hline Coating of $M S U$ with: & $\begin{array}{l}C L \text { max } \\
(m V)\end{array}$ & $\begin{array}{l}\text { Inhibition } \\
(\%)\end{array}$ \\
\hline PBS (uncoated) & $201 \pm 4^{*}$ & \\
$50 \%$ control NHS & $52 \pm 3$ & 74 \\
$50 \%$ LPFS & $152 \pm 4$ & 24 \\
$50 \%$ LPFS reconstituted with VLDL & $91 \pm 7$ & 55 \\
$50 \%$ LPFS reconstituted with LDL & $53 \pm 4$ & 74 \\
$50 \%$ LPFS reconstituted with HDL & $149 \pm 6$ & 26 \\
LDL (1 mg/ml) & $15 \pm 3$ & 92 \\
\hline
\end{tabular}

Coated and uncoated MSU (final concentration $1 \mathrm{mg} / \mathrm{ml}$ ) were added to $2 \times 10^{6}$ neutrophils and $500 \mu \mathrm{l}$ luminol in a final volume of $1.0 \mathrm{ml}$, and $\mathrm{CL}$ monitored at $37^{\circ} \mathrm{C}$. LPFS was reconstituted with original serum concentrations of VLDL, LDL, and HDL.

MSU=monosodium urate crystals; $\quad \mathrm{CL}=$ chemiluminescence; NHS=normal human serum; LPFS=lipoprotein free human serum; VLDL=very low density lipoprotein; $L D L=$ low density lipoprotein; $\mathrm{HDL}=$ high density lipoprotein.

*Data are expressed as the mean $\pm S D$ of the maximum $C L$ response ( $C L$ max) of three experiments.
1250) as previously described. ${ }^{8}$ Human peripheral neutrophils were isolated from heparinised blood by Hypaque-Ficoll separation followed by dextran sedimentation. Contaminating red cells were lysed during a five minute incubation in Gey's solution. Results were expressed as the maximum chemiluminescence response (CL max), defined as the highest recorded light output (in millivolts) integrated over one second intervals.

\section{RAT AIR POUCH FORMATION AND MSU IN JECTION}

The thoracic dorsal region of male hooded Wistar rats $(200-300 \mathrm{~g}$ in weight) was injected subcutaneously with $20 \mathrm{ml}$ sterile air and pouch formation maintained by reinflating with $10 \mathrm{ml}$ air after three days. Pouches were deflated on day seven and injected with uncoated (control) and LDL coated urate crystal suspensions $(20 \mathrm{mg}$ in $5 \mathrm{ml}$ urate saturated PBS). Groups of four rats were killed three hours and six hours after crystal injection and the pouches irrigated with $5 \mathrm{ml}$ saline before withdrawing the fluid for estimation of prostaglandin (PG), protein, and cell number. Total leucocyte counts in the pouch washings were measured in a Coulter counter, and the prostaglandin 6-keto-PGF - $_{1 \alpha}$ (the stable hydrolysis product of prostacyclin) measured by radioimmunoassay as described previously. ${ }^{9}$ Protein was measured according to the method of Pesce and Strande. ${ }^{10}$

\section{Results}

IN VITRO STUDIES

Coating of MSU with NHS markedly depressed the chemiluminescence of crystal induced neutrophils compared with that of uncoated crystals (Table 1). The inhibitory effect was largely reversed by depletion of the lipoprotein fraction from serum (74\% inhibition compared with $24 \%$ inhibition). Reconstitution of LPFS with VLDL and LDL, but not 0 HDL, restored the inhibition (Table 1), confirming apo B lipoproteins as major regulators of the crystal-

Table 2 Comparison of the effects of uncoated and LDL coated MSU on crystal induced inflammation in the rat subcutaneous air pouch

\begin{tabular}{|c|c|c|c|c|c|c|}
\hline \multirow[t]{2}{*}{ Crystal preparation } & \multicolumn{3}{|c|}{ Three hours postinjection } & \multicolumn{3}{|c|}{ Six hours postinjection } \\
\hline & $W C C \times 10^{-6}$ & $\begin{array}{l}\text { 6-Keto-PGFla } \\
(\mathrm{ng} / \mathrm{ml})\end{array}$ & $\begin{array}{l}\text { Protein } \\
(m g / m l)\end{array}$ & $W C C \times 10^{-6}$ & $\begin{array}{l}\text { 6-Keto-PGF } \\
(n g / m l)\end{array}$ & $\begin{array}{l}\text { Protein } \\
(m g / m l)\end{array}$ \\
\hline $\begin{array}{l}\text { Uncoated MSU ( } 20 \mathrm{mg}) \\
\text { LDL coated MSU ( } 20 \mathrm{mg})\end{array}$ & $\begin{array}{l}5 \cdot 6 \pm 1 \cdot 3 \\
5 \cdot 0 \pm 1 \cdot 05\end{array}$ & $\begin{array}{l}12 \cdot 4 \pm 1 \cdot 3^{*} \\
11 \cdot 8 \pm 1 \cdot 0\end{array}$ & $\begin{array}{l}1 \cdot 7 \pm 0 \cdot 2 \\
1 \cdot 9 \pm 0 \cdot 2\end{array}$ & $\begin{array}{l}56 \cdot 2 \pm 12 \cdot 1 \\
57 \cdot 0 \pm 11 \cdot 2\end{array}$ & $\begin{array}{l}18 \cdot 7 \pm 5 \cdot 2 \\
19 \cdot 0 \pm 4 \cdot 7\end{array}$ & $\begin{array}{l}3 \cdot 3 \pm 0 \cdot 3 \\
3 \cdot 3 \pm 0 \cdot 6\end{array}$ \\
\hline
\end{tabular}

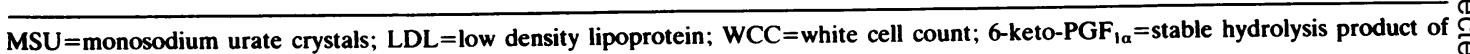
prostacyclin.

*Values represent the mean $\pm \mathrm{SD}$ of four rats. 
neutrophil interaction in this in vitro system. ${ }^{6}$ Coating of MSU with a physiologic concentration of purified LDL $(1 \mathrm{mg} / \mathrm{ml})$ abrogated the neutrophil CL responses $(92 \%$ inhibition compared with uncoated MSU).

\section{IN VIVO STUDIES}

Leucocyte accumulation (greater than $90 \%$ neutrophils), levels of the prostaglandin metabolite 6keto-PGF $1 \alpha$, and protein concentrations in the washouts were no different after injection of uncoated and LDL coated urate crystal suspensions, at both three hours and six hours after crystal injection (Table 2). Injection of urate saturated PBS alone did not raise cell counts or prostanoid levels above unstimulated pouch levels.

\section{Discussion}

Regulation of the phlogistic activity of urate crystals by variable levels of apo B lipoproteins in joint fluid offers an attractive explanation for clinical observations such as the self limiting nature of the acute attack and striking variability in the inflammatory response to urate crystals. ${ }^{11} 12$ Recent work has shown that LDL abrogates a range of cellular responses to MSU, including phagocytosis by neutrophils, platelet serotonin release, and the physical association between crystals and platelets. ${ }^{13}$ The inhibitory properties of LDL are now known not to be specific for urate crystals and are seen with crystals of silica, calcium pyrophosphate dihydrate, and hydroxyapatite, and latex beads ( $R$ Terkeltaub, personal communication). Our results confirm apo B lipoproteins (VLDL, LDL) as major serum inhibitors of the urate crystal-neutrophil interaction, with LDL producing the largest inhibitory effect. Our findings differ slightly from those of Terkeltaub et al, who found that lipoprotein depletion completely reversed the inhibitory effect of a plasma coat on urate induced CL. ${ }^{6}$ Assay conditions such as the presence of non-specific protein, the use of plasma rather than serum, and performance of the $\mathrm{CL}$ assay at $22^{\circ} \mathrm{C}$ may account for this difference.

Since the interaction between urate crystals and cells has an essential role in the development of acute gouty arthritis ${ }^{1}{ }^{14}$ it seemed appropriate to determine the effects of apo B lipoproteins on MSU induced inflammation in vivo. We used a rat air pouch model of facsimile synovium developed by Edwards et $\mathrm{l}^{15}$ to compare inflammatory responses induced by LDL coated and native MSU. Both pouch lining and synovium consisted of flattened fibroblast-like and macrophage-like cells. ${ }^{15}$ Urate crystals injected into the pouch cavity induced an acute inflammatory response characterised by pha- gocytosis of crystals by both types of lining cells, followed by cellular exudate formation with ingestion of crystals by neutrophils and mononuclear leucocytes. ${ }^{9}$ Although coating of MSU with LDL abrogated the activation of human neutrophils in vitro (Table 1), LDL coated and uncoated crystals did not differ in their ability to stimulate cellular influx, synthesis of the prostanoid 6-keto-PGF Pa $_{1 \alpha}$, or exudation of plasma proteins in urate induced air pouch inflammation (Table 2). Thus LDL crystal coating did not appear to exert a protective or antiinflammatory effect in this model.

This observation is difficult to reconcile given the striking inhibitory effect of apo B lipoproteins on cell surface interaction in vitro. It is possible that LDL coating does not effect the activation of mediator systems important for the development of tissue inflammation in the pouch. Alternatively, regions of the LDL coat critical for inhibition of crystal surface activity may be altered or masked in vivo. It would be interesting to study $\mathrm{LDL}$ effects in the neutrophil dependent canine and primate models of urate induced synovitis, which may be closer analogues of natural gouty inflammation. In addition, the effect of LDL on the release of other inflammatory mediators (e.g., lysosomal enzymes, lipoxygenase associated metabolites) deserves further study. The proposed role of apo B lipoproteins as modulators of crystal-cell interactions critical in the expression of gouty arthritis requires further verification by clinical and animal studies before such a mechanism can be fully accepted.

We gratefully thank Mrs M Brown for typing the manuscript and for helpful secretarial assistance. Dr T Gordon was the recipient of a National Heath and Medical Research Council Postgraduate Scholarship.

\section{References}

1 Phelps P, McCarty D J. Crystal-induced inflammation in canine joints. II. Importance of polymorphonuclear leukocytes. J Exp Med 1966; 124: 115-25.

2 Kozin F, Ginsberg M, Skosey J. Polymorphonuclear leukocyte responses to monosodium urate crystals: modification by adsorbed serum proteins. J Rheumatol 1979; 6: 519-26.

3 McMillan R M, Hasselbacher P, Hahn J L, Harris E D. Interactions of murine macrophages with monosodium urate crystals: stimulation of lysosomal enzyme release and prostaglandin synthesis. J Rheumatol 1981; 8: 555-62.

4 Abramson S, Hoffstein S T, Weissman G. Superoxide anion generation by human neutrophils exposed to monosodium urate. Effect of protein adsorption and complement activation. Arthritis Rheum 1982; 25: 174-80.

5 Hasselbacher P. Crystal-protein interactions in crystal-induced arthritis. In: Weissman G, ed. Adv Inflammation Res. New York: Raven, 1982; 25-44.

6 Terkeltaub R, Curtiss L K, Tenner A J, Ginsberg M H. Lipoproteins containing apoprotein $\mathrm{B}$ are a major regulator of neutrophil responses to monosodium urate crystals. J Clin Invest 1984; 73: 1719-30. 
7 Denko C W, Whitehouse M W. Experimental inflammation induced by naturally occurring microcrystalline calcium salts. $J$ Rheumatol 1976; 3: 54-62.

8 Gordon T P, Ahern M J. Reid C, Roberts-Thomson P J. Studies on the interaction of rheumatoid factor with monosodium urate crystals and case report of coexistent tophaceous gout and rheumatoid arthritis. Ann Rheum Dis 1985; 44: 384-9.

9 Gordon T P, Kowanko I C, James M, Roberts-Thomson P J. Monosodium urate crystal-induced prostaglandin synthesis in the rat subcutaneous air pouch. Clin Exp Rheumatol 1985; 3: 291-6.

10 Pesce M A, Strande C S. A new micromethod for determination of protein in cerebrospinal fluid and urine. Clin Chem 1973; 19: 1265-7.

11 Weinberger A, Schumacher H R, Agudelo C A.Urate crystals in asymptomatic metatarsophalangeal joints. Ann Intern Med 1979; 91: 56-7.

12 Gordon T P, Bertouch J V, Walsh B R, Brooks P M. Monosodium urate crystals in asymptomatic knee joints. $J$ Rheumatol 1982; 9: 967-9.

13 Terkeltaub R, Smeltzer D, Curtiss L, Ginsberg M H. Low density lipoprotein inhibits the physical interaction of phlogistic crystals and inflammatory cells. Arthritis Rheum (in press).

14 Wigley F. Fine I, Newcombe D. The role of the human synovial fibroblast in monosodium urate crystal-induced synovitis. $J$ Rheumatol 1983; 10: 602-11.

15 Edwards J C, Sedgwick A D, Willoughby D A. The formation of a structure with the features of synovial lining by subcutaneous air: an in vivo tissue culture system. J Pathol 1981; 134: $147-56$. 